\title{
Anti-IFN- $\gamma$ Antibody Promotes Osteoclastogenesis in Human Bone Marrow Monocyte-Derived Macrophages Co-Cultured with Tuberculosis-Activated Th1 Cells
}

\author{
Jiezhong Deng Dong Sun Fei Luo Qiang Zhang Feifan Chen Jianzhong Xu
} Zehua Zhang

Department of Orthopedics, Southwest Hospital, The First Affiated Hospital of Army Medical University, Chonggqing, China

\section{Key Words}

Tuberculosis • Th1 cells • Osteoclastogenesis • Interferon- $\gamma$

\begin{abstract}
Background/Aims: Tuberculosis induces bone loss and activates Th1 cells that play an important role in the host defense of Bacille Calmette-Guérin tuberculosis vaccine. However, the role of tuberculosis-activated Th1 cells in differentiation of osteoclast precursors to osteoclasts is unclear. As secretion of IFN- $\gamma$ in Th1 cells is induced by tuberculosis, we aimed to investigate the role of anti-IFN- $\gamma$ antibody on the differentiation and activation of osteoclasts in bone marrow monocyte-derived macrophages (BMMs). Methods: BMMs were isolated and co-cultured with CD4+T helper 1 cells (Th1 cells), pretreated with anti-IFN- $\gamma$ antibody. Then, cell proliferation, expression and release of cytokines, formation of actin ring, differentiation of osteoclasts and bone resorption function were measured by CCK8 assay, qRT-PCR/Western blot/flow cytometry, ELISA, immunofluorescence, tartrate-resistant acidic phosphatase (TRAP) staining and bone absorbance assay, respectively. Results: Anti-IFN $-\gamma$ antibody inhibited the cell viability of BMMs, and induced the expressions of RANKL, TNF- $\alpha, N F-K B$ and TRAF6 in BMMs. In addition, it led to increased expression levels of RANK on cell surfaces, and increased production of RANKL, TNF- $\alpha$, MCP- 1 and SDF-1. Anti-IFN- $\gamma$ antibody also induced the expression of osteoclast differentiation factor and actin ring formation, but inhibited the expression of osteoprotegerin. TRAP staining and bone resorption assays showed that antiIFN- $\gamma$ antibody induced an increase in osteoclast formation and bone resorption. Conclusion: The anti-IFN- $\gamma$ antibody induced osteoclast formation, and is probably mediated by RANKL-
\end{abstract}




\section{Cellular Physiology Cell Physiol Biochem 2018;49:1512-1522 and Biochemistry \begin{tabular}{l|l} 
DOI: 10.1159/000493455 & (c) 2018 The Author(s). Published by S. Karger AG, Basel \\
www.karger.com/cpb
\end{tabular} \\ Deng et al.: Anti-IFN- $\gamma$ Antibody Induced Osteoclast Formation}

induced activation of NF-KB, that induces TRAF6 in the RANKL-RANK signaling pathway. Our data suggest an inhibitory role for IFN $-\gamma$ in osteoclast formation induced by tuberculosis.

(C) 2018 The Author(s)

Published by S. Karger AG, Basel

\section{Introduction}

Tuberculosis continues to be a public health problem worldwide. Extra-pulmonary tuberculosis accounts for one-third of all types of tuberculosis. Osteoarthritis tuberculosis is one of the main manifestations of extra-pulmonary tuberculosis, and accounts for $35 \sim 50 \%$ of extra-pulmonary tuberculosis. Osteoarthritis tuberculosis is a chronic and progressive disease caused by Mycobacterium tuberculosis and is characterized by bone loss due to an imbalance in bone remodeling and bone resorption [1-3].

Bone formation and bone resorption are coupled processes and together function to maintain dynamic bone equilibrium [4,5]. Osteoblasts and osteoclasts are basic functional cells that participate in bone remodeling. Indeed, osteoclasts are the only highly specific multinucleated giant cells with bone resorption function in vivo [6]. Osteoclasts differentiate from osteoclast precursor cells in the bone marrow monocyte-phagocytic system, such as bone marrow monocyte-derived macrophages (BMMs)[7]. After infection around the bone, bacterial endotoxins and various inflammatory factors induce activation and proliferation of osteoclasts, inhibit the activity of osteoblasts, cause disequilibrium in bone metabolism, and finally induce pathological bone resorption [1-3]. Several studies have confirmed that the differentiation process of osteoclasts involves the regulation of NF-kappa B activation receptor (RANK) / osteoprotegerin (OPG)/RANK ligand (RANKL) axis system [8]. The axis is activated by microbiological antigens, denatured collagen and various chemokines and inflammatory factors, and is the main regulatory mechanism mediating osteoclast differentiation and maturation [9-11]. Moreover, inhibition of osteoclastogenesis is also inhibited by the RANKL/ROS/JAK2 pathway $[12,13]$.

The cellular immune response mediated by $\mathrm{CD} 4+\mathrm{T}$ helper cells (Th cells) greatly impacts resorption of bone in the host $[14,15]$. The activated Th cells secrete cytokines that exert different effects through different signaling pathways, and play an important role in the regulation of bone immunity [16]. Studies suggest that differentiation of Th1 from the initial CD4+T cell population predominates in the early/stable stage of bone disease [17]. Th1 cells mediate the cellular immune response, mainly through the secretion of interferon- $\gamma$ (INF- $\gamma$ ). Most studies suggest that INF- $\gamma$ produced by activated Th1 strongly inhibits the differentiation of osteoclast precursor cells into osteoclasts in vitro $[18,19]$. IFN- $\gamma$ strongly inhibits RANKL-induced activation of the transcription factors NF- $\kappa B$ and JNK by inducing rapid degradation of the adapter protein TRAF6 in the RANKL-RANK signaling pathway, blocking the entire RANKL-RANK signaling pathway and eventually inhibiting osteoclast formation [20]. The role of IFN- $\gamma$ in the differentiation of osteoclast precursors depends on the complex regulation of the environment in which the cells are located and the inflammatory signaling pathways.

Tuberculosis induces bone loss by activating RANKL signaling [21]. Tuberculosisactivated Th1 cells play an important role in immune response in tuberculosis [22]. However, the role of tuberculosis-activated Th1 cells in differentiating osteoclast precursors to osteoclasts is unclear. Th1 cells in tuberculosis patients produce increasing levels of IFN- $\gamma$ $[22,23]$. In the present study, we co-cultured BMMs with isolated Th1 cells, and investigated the effects of anti-IFN- $\gamma$ antibody on bone resorption and differentiation.

\section{Materials and Methods}

Tuberculosis sensitized Th1 cells

BALB/c mice ( $n=6$, weight 20-25 g) were purchased from the Laboratory Animal Center of The First Affiliated Hospital of Army Medical University. Mononuclear lymphocytes were collected from normal 


\section{Cellular Physiology Cell Physiol Biochem 2018;49:1512-1522 \begin{tabular}{l|l|l} 
and Biochemistry Published online: 13 September, 2018 & $\begin{array}{l}\text { (c) } 2018 \text { The Author(s). Published by S. Karger AG, Basel } \\
\text { www.karger.com/cpb }\end{array}$
\end{tabular} \\ Deng et al.: Anti-IFN- $\gamma$ Antibody Induced Osteoclast Formation}

BALB/c mice spleens by grinding, screen mesh filtration, and Ficoll density gradient centrifugation at 2, $000 \mathrm{r} / \mathrm{min}$ for $20 \mathrm{~min}$. This research was supported by the Research Ethics Committee of The First Affiliated Hospital of Army Medical University. T cells were removed after incubating the mice spleen cells with antimouse CD4+ and CD8+T, and anti-Thyl antibodies (BD Bioscience, USA). Then, the cells were re-suspended in RPMI-1640 (Gibco, USA) containing 10\% fetal bovine serum, and treated with mitomycin (Sigma, USA). After centrifugation for $10 \mathrm{~min}$ at $1,800 \mathrm{r} / \mathrm{min}$ and removal of supernatant, the antigen presenting cells were prepared. The CD4+T cells were isolated by magnetic beads (Mihenyi's, Germany). Flow cytometry showed that CD4+T cells of $>99 \%$ were positive for TCR-Tg by staining with anti TCR-Tg specific antibody (BD Bioscience).

For tuberculosis, TCR-Tg CD4+T cells and antigen presenting cells (1:6) were cultured for 3-4 days in the presence of Bacille Calmette-Guérin (BCG, China Biotechnology co. LTD) and IL-12 (2 ng/ml, PeproTech, USA). Then, cells were incubated with IL-2 (10 $\mathrm{g} / \mathrm{m} 1$, PeproTech). Cells were passaged over 3 days at a time. The third passage Th1 cells were mixed with antigen presenting cells (1:6), treated with BCG (1 $\mu \mathrm{g} /$ $\mathrm{m} 1$ ) for $5 \mathrm{~h}$, and then pre-incubated with anti-IFN- $\gamma$ antibody for $24 \mathrm{~h}$ and used in subsequent experiments.

\section{Isolation of mouse bone marrow monocyte/macrophage cell line (BMMs)}

Mouse femoral and tibial canal lavage fluids were placed in a $50 \mathrm{ml}$ centrifuge tube containing 3, 000 $\mathrm{u}$ heparin, diluted with $20 \mathrm{ml}$ PBS, and slowly added to $20 \mathrm{ml}$ Ficoll $(1.077 \mathrm{~g} / \mathrm{ml}$, Solarbio, China). After centrifugation at $1,500 \mathrm{rpm}$, for $20 \mathrm{~min}$ at $20^{\circ} \mathrm{C}$ monocytes were collected and re-suspended in RPMI-1640 containing $10 \%$ new calf serum.

\section{Co-culture of BMMs and Th1 cells}

Transwells with $0.4 \mu \mathrm{m}$ diameter polycarbonate membranes were selected to conduct non-contact coculture of BMMs and Th1 cells with 24 -well plates. BMMs were seeded in the upper chamber $\left(5 \times 10^{5}\right.$ cells $)$ and Th1 $\left(6 \times 10^{3}\right.$ cells $)$ cells were seeded in the lower chamber. Th1 cells were pre-incubated with anti-IFN- $\gamma$ antibody for $24 \mathrm{~h}$, and the adherent BMMs were treated with recombinant human M-CSF (rhM-CSF, $25 \mathrm{ng} /$ $\mathrm{mL}$, PeproTech) and human recombinant RANKL (rhRANKL, $30 \mathrm{ng} / \mathrm{mL}$, PeproTech). Osteoclast formation was evaluated after 6 days of culture.

\section{Enzyme Linked Immunosorbent Assay (ELISA)}

The adherent BMMs were cultured with Th1 cells, with or without pre-incubated anti-IFN- $\gamma$ antibody for $24 \mathrm{~h}$, in the presence of rhM-CSF and rhRANKL for 6 days. Then, levels of IFN- $\gamma$, TNF- $\alpha$, MCP-1, RANKL and SDF-1 were examined using an ELISA kit (Elabscience, USA), according to the manufacturer's instructions. After incubation with biotinylated antibody ( $100 \mu \mathrm{L} /$ well) for $1 \mathrm{~h}$ at 37 ? , the plates were washed 5 times in PBS, incubated with enzyme substrate for $30 \mathrm{~min}$ at $37^{\circ} \mathrm{C}$ and then with chromogenic substrate $3,3^{\prime}, 5$, $5^{\prime}$-Tetramethylbenzidine (TMB) solution for $15 \mathrm{~min}$ at $37^{\circ} \mathrm{Cin}$ the dark. The reaction was terminated by 100 $\mu \mathrm{L}$ stop solution. The optical density was read by a microplate reader at $450 \mathrm{~nm}$.

\section{qRT-PCR}

After treatment, total RNA from BMMs was isolated using Trizol reagent (Invitrogen), according to the standard protocol. qRT-PCR was performed using the SYBR Premix Ex TaqTM (Takara, Shiga, Japan) using Real-Time PCR System (Applied Biosystems, USA), according to the manufacturer's instructions. The primers used in this study are listed in Table 1. The tests were performed in triplicate. Gene expression was normalized to GAPDH expression, and calculated using the method of $2^{-\Delta \Delta C t}$.

Table 1. The primer sequence used in qRT-PCR

\begin{tabular}{|c|c|c|}
\hline ID & Sequence $\left(5^{\prime}-3^{\prime}\right)$ & Product Length(bp) \\
\hline$\beta$-actin F & CATTGCTGACAGGATGCAGA & 139 \\
\hline$\beta$-actin R & CTGCTGGAAGGTGGACAGTGA & \\
\hline IFN- $\gamma$ F & ACAGCAAGGCGAAAAAGGATG & 106 \\
\hline IFN- $\gamma \mathrm{R}$ & TGGTGGACCACTCGGATGA & \\
\hline$N F-\kappa B F$ & TGCGATTCCGCTATAAATGCG & 178 \\
\hline$N F-\kappa B R$ & ACAAGTTCATGTGGATGAGGC & \\
\hline TNF- $\alpha \mathrm{F}$ & CCTGTAGCCCACGTCGTAG & 148 \\
\hline TNF- $\alpha \mathrm{R}$ & GGGAGTAGACAAGGTACAACCC & \\
\hline TRAF6 F & AAAGCGAGAGATTCTTTCСCTG & 125 \\
\hline TRAF6 R & ACTGGGGACAATTCACTAGAGC & \\
\hline RANKL F & CGCTCTGTTCCTGTACTTTCG & 114 \\
\hline RANKL R & GAGTCCTGCAAATCTGCGTT & \\
\hline
\end{tabular}




\section{Cellular Physiology Cell Physiol Biochem 2018;49:1512-1522

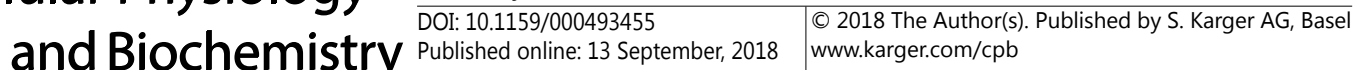

\section{Western blot}

Proteins were extracted from BMMs using the RIPA lysis buffer and quantified by Pierce BCA Protein Assay Kit (Thermo, USA). Proteins were separated by 10\% SDS-PAGE and then transferred onto a nitrocellulose membrane. After blocking with 5\% skim milk, and incubating with primary antibodies that included anti-GAPDH, IFN- $\gamma$, RANKL, TNF- $\alpha$, NF- $\kappa$ B (p65), TRAF6 and osteoprotegerin (OPG) (Abcam, USA) overnight at $4^{\circ} \mathrm{C}$, the membranes were treated with HRP-conjugated secondary antibody (Bioworld, China) for $1 \mathrm{~h}$ at room temperature. The blots were visualized using the ECL-Plus reagent (Millipore, Billerica, MA, USA).

Flow cytometry detection of RANK on the cell surface

The adherent BMMs were cultured with Th1 cells, with or without pre-incubated anti-IFN- $\gamma$ antibody for $24 \mathrm{~h}$, in the presence of rhM-CSF and rhRANKL for 6 days. Then, BMMs were incubated with 2 mL FACS lysing solution at $25^{\circ} \mathrm{C}$ for $10 \mathrm{~min}$, and incubated with FITC-conjugated anti-human RANK antibodies (Becton Dickinson) at $25^{\circ} \mathrm{C}$ for $30 \mathrm{~min}$ in the dark. The stained cells were analyzed using a FACS scan.

\section{Cell viability detection by CCK8}

The adherent BMMs were cultured with Th1 cells, with or without pre-incubated anti-IFN- $\gamma$ antibody $(1,5$ and $10 \mu \mathrm{g} / \mathrm{ml})$ for $24 \mathrm{~h}$, in the presence of rhM-CSF and rhRANKL for 24, 48, and $72 \mathrm{~h}$. Then, BMMs were incubated with CCK8 solution (Beyotime, China) at $37^{\circ} \mathrm{C}$ for $2 \mathrm{~h}$. Cell viability was detected by a microplate reader at $450 \mathrm{~nm}$.

\section{Immunostaining of F-actin}

After treatments, BMMs were fixed with 4\% paraformaldehyde in PBS for $15 \mathrm{~min}$ and permeabilized with $100 \%$ methanol for $10 \mathrm{~min}$ at $-20^{\circ} \mathrm{C}$. After blocking with $2 \%$ goat serum for $60 \mathrm{~min}$, the cells were treated with primary antibody against F-actin (1:100, Abcam, USA) and incubated overnight at $4^{\circ} \mathrm{C}$. After incubating with fluorochrome-conjugated secondary antibody for $1 \mathrm{~h}$ at room temperature in the dark, the nuclei were stained using DAPI. The images were captured by FV10i Confocal Microscope (Olympus, Japan).

Tartrate-resistant acidic phosphatase (TRAP) staining

The adherent BMMs were cultured with Th1 cells with or without pre-incubated anti-IFN- $\gamma$ antibody for $24 \mathrm{~h}$, in the presence of rhM-CSF and rhRANKL for 6 days. Then, TRAP staining was performed using a TRAP staining kit (Sigma, USA) at $25^{\circ} \mathrm{C}$ Slides were viewed using a light microscope (10X, IX71, Olympus, Japan).

\section{Bone absorbance assay}

The adherent BMMs were cultured with Th1 cells with or without pre-incubated anti-IFN- $\gamma$ antibody for $24 \mathrm{~h}$, in the presence of rhM-CSF and rhRANKL for 6 days. Then, bone resorption function of differentiated osteoclasts was evaluated by the OsteoAssay Plate. Cells were seeded on plates. After induction by antiIFN- $\gamma$ antibody, the medium was removed, and $10 \%$ bleach was added. After $5 \mathrm{~min}$, the plates were washed in $\mathrm{ddH}_{2} \mathrm{O}$ for $5 \mathrm{~min}$. The formation of lacuna was observed on plates and imaged by light microscopy (10X, IX71, Olympus, Japan).

\section{Statistical analysis}

Data were performed in triplicate and presented as means \pm standard deviation. The analysis was performed by SPSS 16.0 using student t-tests for two groups, and one-way ANOVA with SNK for multiple group comparisons. $P<0.05$ was considered to be statistically significant.

\section{Results}

Anti-IFN- $\gamma$ antibody suppressed cell proliferation and secretion of IFN- $\gamma$, but promoted the production of $R A N K L, T N F-\alpha, M C P-1$ and $S D F-1$

To evaluate the role of IFN- $\gamma$ on the viability of BMMs and tuberculosis-activated Th1 cells, BMMs were co-cultured with Th1 cells that were pre-treated with anti-IFN- $\gamma$ antibody 


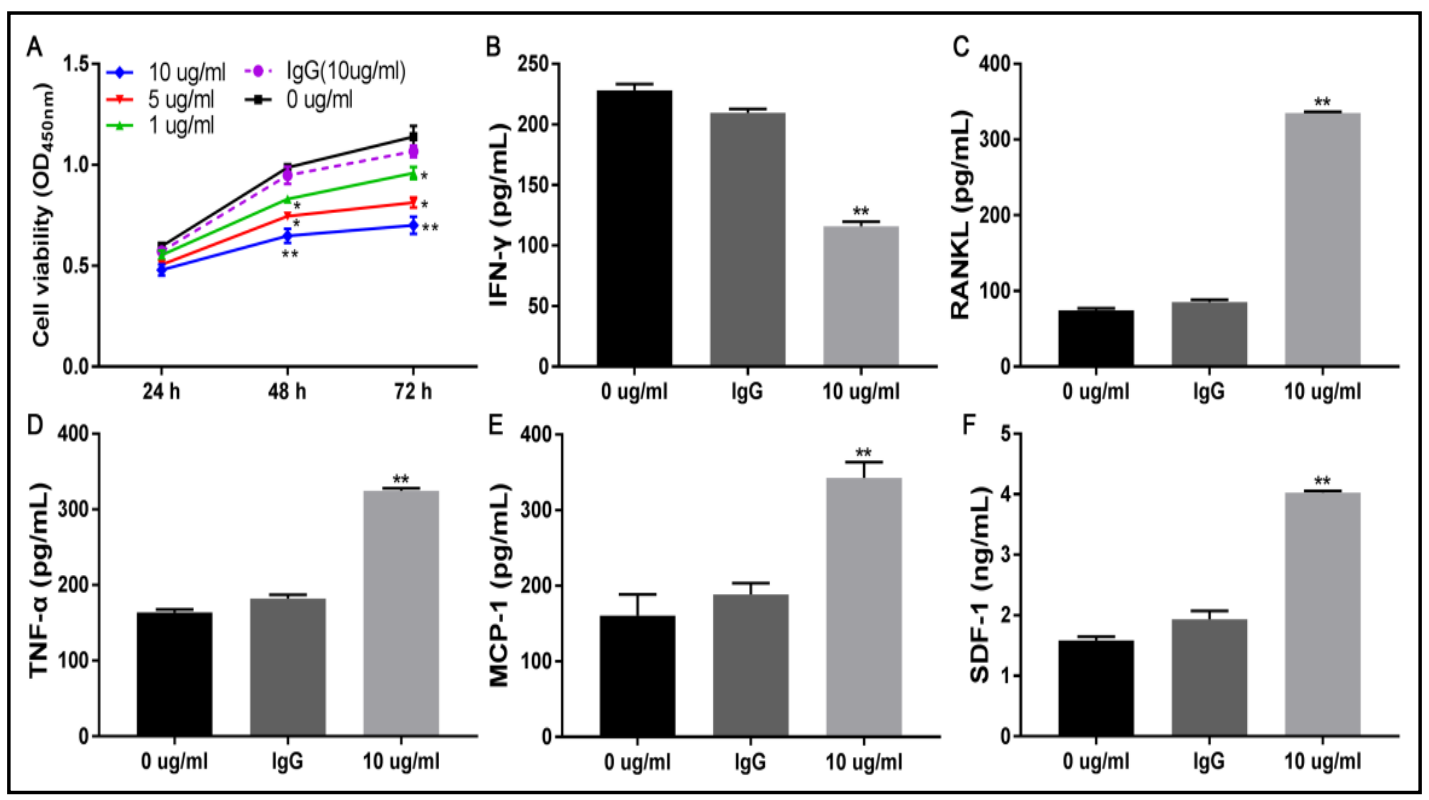

Fig. 1. Effect of anti-IFN- $\gamma$ antibody on proliferation and levels of IFN- $\gamma$, RANKL, TNF- $\alpha$, MCP-1 and SDF-1 in BMMs. After pre-incubation with rabbit IgG $(10 \mu \mathrm{g} / \mathrm{mL})$ or anti-IFN- $\gamma$ antibody $(0,1,5$ or $10 \mu \mathrm{g} / \mathrm{mL})$, Th1 cells were co-cultured with BMMs for 24,48 , and $72 \mathrm{~h}$, (A) cell viability of BMMs was detected by CCK8 assay. Data showed that the optimal conditions for IFN- $\gamma$ treatment were $10 \mu \mathrm{g} / \mathrm{ml}$ for $48 \mathrm{~h} .{ }^{*} \mathrm{P}<0.05$, ${ }^{* *} \mathrm{P}<0.01$ vs. $0 \mu \mathrm{g} / \mathrm{ml}$. Then, after pre-incubation with rabbit IgG $(10 \mu \mathrm{g} / \mathrm{mL})$, anti-IFN- $\gamma$ antibody $(0$ or 10 $\mu \mathrm{g} / \mathrm{mL}$ ) for $24 \mathrm{~h}$, Th1 cells were co-cultured with BMMs for 6 days. Levels of (B) IFN- $\gamma$, (C) RANKL, (D) TNF- $\alpha$, (E) MCP-1 and (F) SDF-1 in culture media were examined by ELISA assay. Data represent the average value calculated form three independent experiments. ${ }^{*} \mathrm{P}<0.05,{ }^{* *} \mathrm{P}<0.01 \mathrm{vs} .0 \mu \mathrm{g} / \mathrm{ml}$.

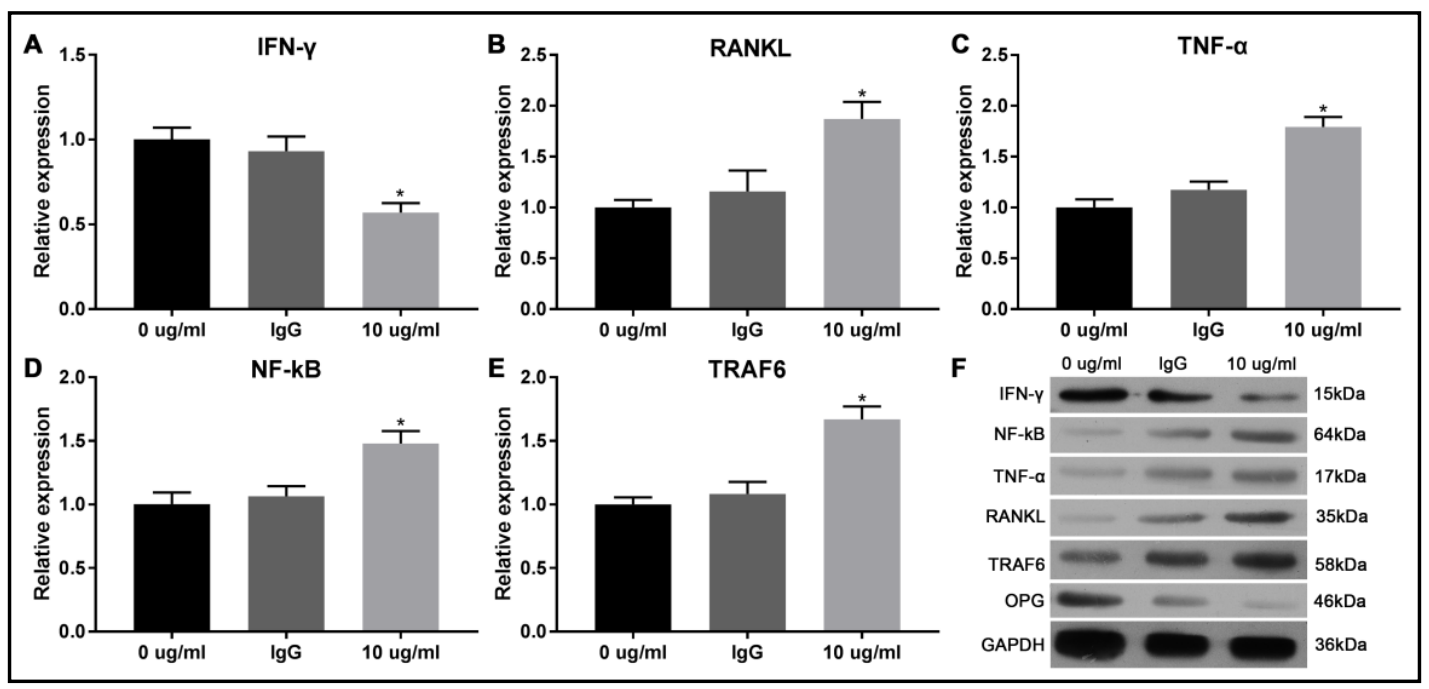

Fig. 2. Effect of anti-IFN- $\gamma$ antibody on expression of IFN- $\gamma$, RANKL, TNF- $\alpha$, NF- $\kappa B$ (p65), TRAF6 and OPG in BMMs. After pre-incubation with rabbit IgG $(10 \mu \mathrm{g} / \mathrm{mL})$, anti-IFN- $\gamma$ antibody (0 or $10 \mu \mathrm{g} / \mathrm{mL})$ for 24 h, Th1 cells were co-cultured with BMMs for 6 days. Then, (A) mRNA levels of IFN- $\gamma$, RANKL, TNF- $\alpha$, NF$\kappa B(p 65)$ and TRAF6 were examined by qRT-PCR. Data represent the average values calculated form three independent experiments. ${ }^{*} \mathrm{P}<0.05$, vs. $0 \mu \mathrm{g} / \mathrm{ml}$.(B) Protein levels of IFN- $\gamma$, RANKL, TNF- $\alpha$, NF- $\kappa B$ (p65), TRAF6 and OPG were examined by Western blots. 


\section{Cellular Physiology Cell Physiol Biochem 2018;49:1512-1522 \begin{tabular}{l|l} 
DOI: 10.1159/000493455 & $\begin{array}{l}\text { O 2018 The Author(s). Published by S. Karger AG, Basel } \\
\text { www.karger.com/cpb }\end{array}$
\end{tabular} \\ Deng et al.: Anti-IFN- $\gamma$ Antibody Induced Osteoclast Formation}

$(1,5$, or $10 \mu \mathrm{g} / \mathrm{mL}$ for 24,48 , and $72 \mathrm{~h}$, respectively. As shown in Fig. $1 \mathrm{~A}$, the CCK-8 assay revealed that cell viability of BMMs was significantly inhibited in a dose-dependent manner. In contrast, the negative control rabbit IgG antibody did not exhibit any significant changes in cell viability. These results suggested the optimal treatment condition of anti-IFN- $\gamma$ antibody was $10 \mu \mathrm{g} / \mathrm{ml}$ for $48 \mathrm{~h}$, which was selected for subsequent experiments.

For chemokine production, pretreatment of tuberculosis-activated Th1 cells with antiIFN- $\gamma$ antibody, inhibited the production of IFN- $\gamma$ (Fig. 1B), but promoted the production of RANKL (Fig. 1C), TNF- $\alpha$ (Fig. 1D), MCP-1 (Fig. 1E) and SDF-1 (Fig. 1F) in co-cultured cells, by ELISA assay.

Anti-IFN- $\gamma$ antibody reduced IFN- $\gamma$ and OPG levels, but increased RANKL, TNF- $\alpha, N F-\kappa B$, and TRAF6 levels in BMMs

To investigate the mechanism of osteoclast differentiation by tuberculosis-activated Th1 cells pretreated with anti-IFN- $\gamma$ antibody, we measured changes in levels of IFN- $\gamma$, OPG, RANKL, TNF- $\alpha$, NF- $\kappa B$, and TRAF6 in BMMs. After co-cultured BMMs and Th1 cells were treated with $10 \mu \mathrm{g} / \mathrm{ml}$ of anti-IFN- $\gamma$ antibody for 6 days, the mRNA and protein levels of IFN- $\gamma$ were significantly decreased (Fig. $2 \mathrm{~A}$ and $\mathrm{F}$ ), whereas the mRNA and protein levels of RANKL (Fig. 2B and F), TNF- $\alpha$ (Fig. 2C and F), NF- $\kappa$ B (Fig. 2D and F), and TRAF6 (Fig. 2E and F) were significantly increased. Moreover, the expression of OPG levels in BMMs were significantly inhibited by anti-IFN- $\gamma$ antibody (Fig. 2F).

anti-IFN- $\gamma$ antibody promoted osteoclastogenesis in BMMs

To evaluate osteoclastogenesis in the presence of anti-IFN- $\gamma$ antibody, we first detected the changes in RANK levels and actin ring formation (Fig. 3). After co-cultured BMMs and Th1 cells were treated with $10 \mu \mathrm{g} / \mathrm{ml}$ of anti-IFN- $\gamma$ antibody for 6 days, RANKL levels in BMMs were significantly increased (Fig. 3A). Moreover, immunostaining of F-actin showed that anti-IFN- $\gamma$ antibody increased actin ring formations in the peripheral margin of the BMMs (Fig. 3B), indicating that anti-IFN- $\gamma$ antibody promotes the differentiation of osteoclasts.

\section{anti-IFN- $\gamma$ antibody promoted resorption in BMMS}

To confirm that osteoclasts are generated by stimulating BMMs with anti-IFN- $\gamma$ antibody, TRAP staining and bone absorbance assays were performed (Fig. 4). As shown in Fig. 4A and C, TRAP-positive multinucleated cells (containing three or more nuclei) dramatically improved when co-cultured with BMMs and $10 \mu \mathrm{g} / \mathrm{ml}$ of anti-IFN- $\gamma$ antibody-pretreated Th1 cells. In addition, the ability to form bone lacuna increased significantly (Fig. 4B and D) in the presence of anti-IFN- $\gamma$ antibody. Both assays showed that anti-IFN- $\gamma$ antibody induced osteoclast formation. 


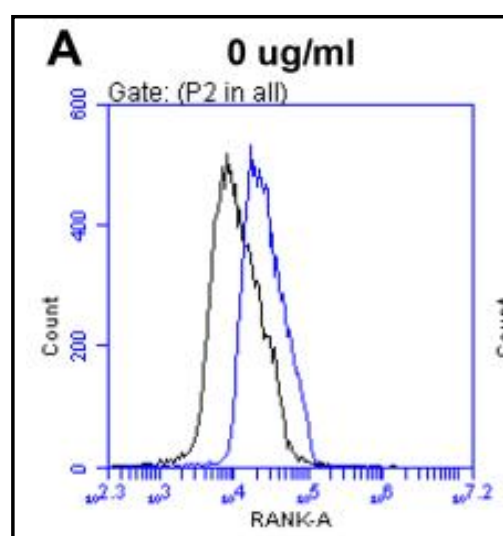

B

F-actin
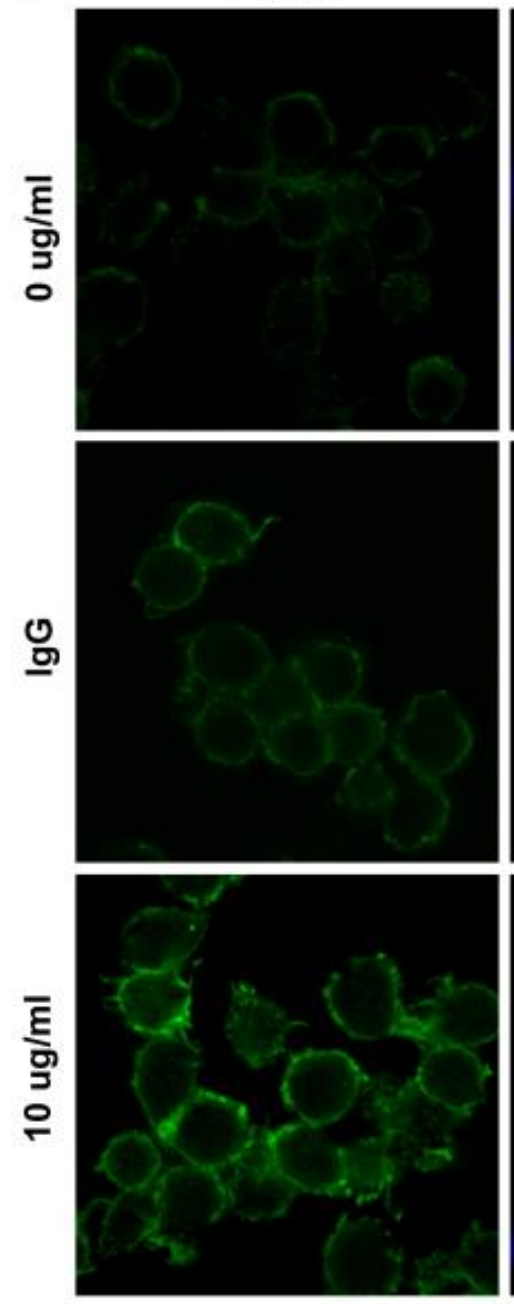

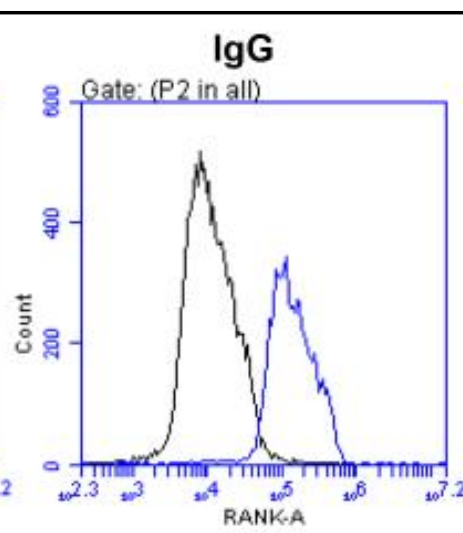

DAPI
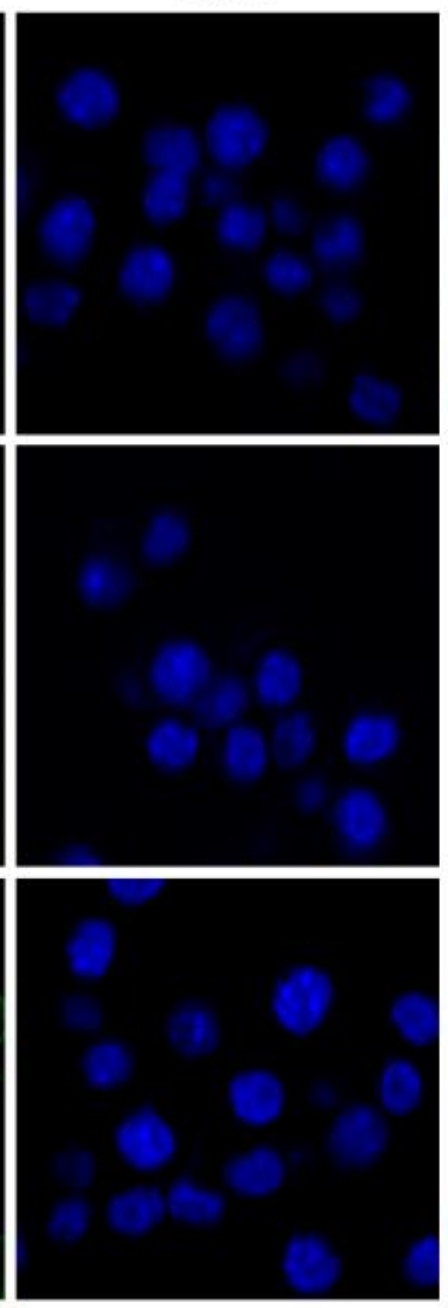

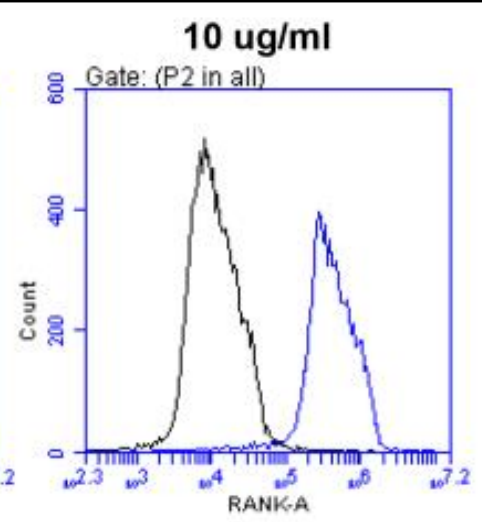

Merge
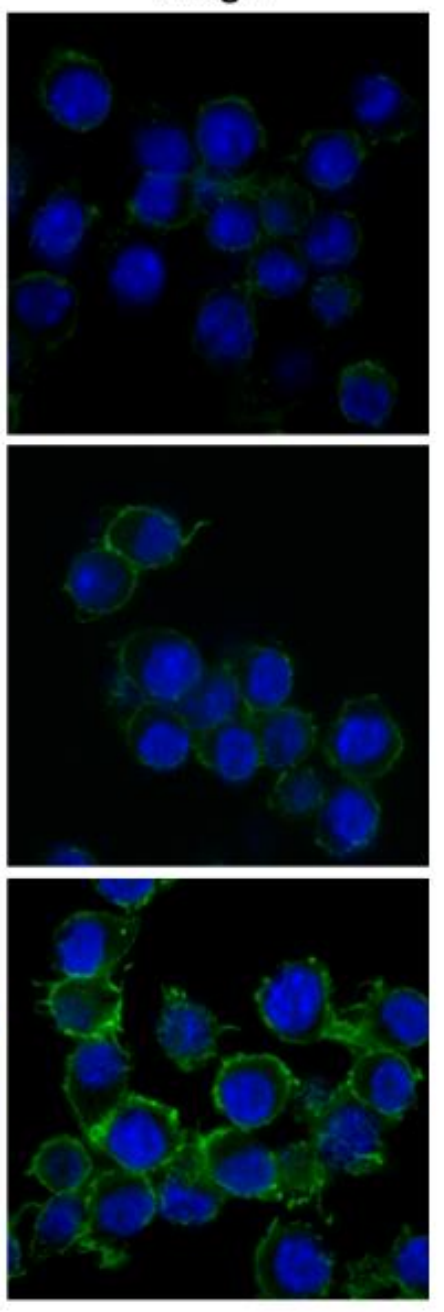

Fig. 3. Effect of anti-IFN- $\gamma$ antibody on expression of RANK and F-actin in BMMs. After pre-incubation with rabbit IgG $(10 \mu \mathrm{g} / \mathrm{mL})$, and anti-IFN- $\gamma$ antibody (0 or $10 \mu \mathrm{g} / \mathrm{mL})$ for $24 \mathrm{~h}$, Th1 cells were co-cultured with BMMs for 6 days, then flow cytometry analysis of RANK (A) and immunostaining of F-actin (B) were performed. Magnification: 120×. 


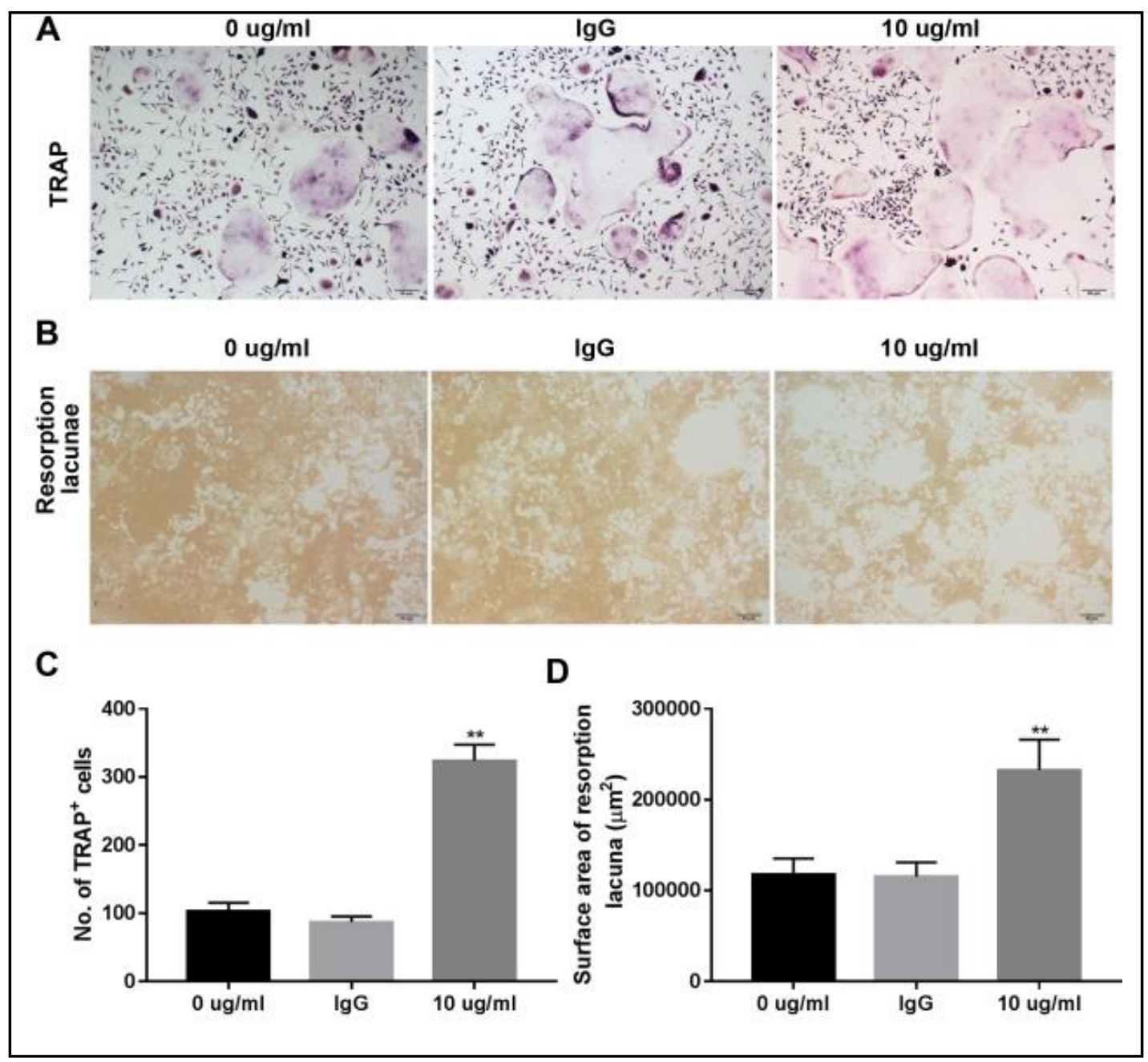

Fig. 4. Effect of anti-IFN- $\gamma$ antibody on the resorption function of BMMs. After pre-incubation with rabbit IgG $(10 \mu \mathrm{g} / \mathrm{mL})$, anti-IFN- $\gamma$ antibody ( 0 or $10 \mu \mathrm{g} / \mathrm{mL}$ ) for $24 \mathrm{~h}$, Th1 cells were co-cultured with BMMs for 6 days, then (A and $\mathrm{C}$ ) the mature osteoclasts were detected by TRAP staining and the number of multinucleated $\mathrm{TRAP}^{+}$cells was quantified by light microscopy. Scale bars: $50 \mu \mathrm{m}$. (B and D) the lacunar number formed after bone resorption was observed by bone absorbance assay and the surface area of resorption lacuna was quantified. Scare bars: $50 \mu \mathrm{m}$. Data represent the average value calculated form three independent experiments. ${ }^{* *} \mathrm{P}<0.01$ vs. $0 \mu \mathrm{g} / \mathrm{ml}$.

\section{Discussion}

In 2000, Joseph et al. put forward the concept of bone immunity, suggesting that there are common cytokines, transcription factors and receptors between immune cells and bone cells, which influence bone remodeling through cell-cell interactions and secretion factors [24]. Studies have demonstrated that activated T cells express RANKL and induce osteoclast differentiation, maturation and activation by binding to RANK on the surface of osteoclast precursors. It was further suggested that activated $\mathrm{T}$ cells affect bone metabolism and promote the formation of osteoclast and subsequent bone resorption by expressing RANKL in vivo and in vitro $[25,26]$. In the present study, our results demonstrate that anti-IFN- $\gamma$ antibody inhibits the expression of IFN $-\gamma$ in Th1 cells and inhibits the cell proliferation and expression of OPG, promotes the expression and secretion of RANKL, TNF- $\alpha$, MCP- 1 and SDF1 and expression of NF- $\mathrm{KB}$ and TRAF6. Consistently, the increase in actin ring formation,

\section{KARGER}




\section{Cellular Physiology Cell Physiol Biochem 2018;49:1512-1522 \begin{tabular}{l|l} 
DOI: 10.1159/000493455 & and Biochemistry \\
Published online: 13 September, 2018 & $\begin{array}{l}\text { O } 2018 \text { The Author(s). Published by S. Karger AG, Basel } \\
\text { www.karger.com/cpb }\end{array}$
\end{tabular} \\ Deng et al.: Anti-IFN- $\gamma$ Antibody Induced Osteoclast Formation}

TRAP staining, and bone resorption further suggest that anti-IFN- $\gamma$ antibody promotes differentiation and activation of osteoclasts.

The Mycobacterium tuberculosis is mainly present in macrophages, and causes pathological changes in the body by stimulating the peripheral blood $\mathrm{T}$ lymphocytes [27]. Tuberculosis of bone refers to the Mycobacterium tuberculosis invading the bones or joints [28]. If the diagnosis and treatment of bone tuberculosis is not timely, it can cause spinal deformity, limited activity, and even paraplegia, seriously affecting the quality of life of the patients. Mycobacterium tuberculosis invades the body and multiplies in cells and causes an inflammatory response and therefore, disrupts the function of the immune system [29]. The immune mechanism of the host cells, thus plays an important role in the growth of Mycobacterium tuberculosis. TNF- $\alpha$ is a cytokine produced by lipopolysaccharidemediated macrophages, and has a variety of biological activities. IFN- $\gamma$ is a lymphocyte-type interferon that constitutes a group of active cytokines with multiple functions produced by monocytes and lymphocytes. IFN- $\gamma$ is expressed in bone tuberculosis tissues, and exhibits low expression in epithelial cells and lymphocytes, indicating that Mycobacterium tuberculosis invades the body and reduces the immune regulation ability of the body [30, 31]. Most studies suggest that INF- $\gamma$ produced by activated Th1, strongly inhibits the in vitro differentiation of osteoclast precursor cells into osteoclasts $[18,19]$. Kohara et al. reported that TNF- $\alpha$ induces the formation of osteoclasts [32]. IFN- $\gamma$ directly inhibits the induction of osteoclasts by TNF- $\alpha$ by promoting Fas/FasL signaling-mediated osteoclast precursor cell apoptosis [32]. Takayanagi et al. found that IFN- $\gamma$ strongly inhibits RANKL-induced activation of the transcription factors NF- $\mathrm{KB}$ and JNK by inducing rapid degradation of the adapter protein TRAF6 in the RANKL-RANK signaling pathway, blocking the entire RANKLRANK signaling pathway and eventually inhibiting osteoclast formation [20]. In addition, Cheng et al. reported that IFN- $\gamma$ inhibits the expression of genes that induce monocyte differentiation into osteoclasts by inhibiting the expression of NFATc1 and activation of NF$\kappa \mathrm{B}$ and JNK signaling [33]. In contrast, our results showed that anti-IFN- $\gamma$ antibody inhibited the expression of IFN- $\gamma$ in Th1 cells and promoted the secretion of RANKL and TNF- $\alpha$, and the expressions of NF- $\kappa$ B and TRAF6. These data imply that anti-IFN- $\gamma$ antibody induces RANKLinduced activation of the transcription factors NF- $\kappa B$ by inducing the adapter protein, TRAF6 in the RANKL-RANK signaling pathway, and eventually promoting osteoclast formation. Our data further suggest that IFN- $\gamma$ influences osteoclastogenesis in BMMs through the RANKLRANK signaling pathway.

\section{Conclusion}

The anti-IFN- $\gamma$ antibody induces osteoclast formation, probably via RANKL-induced activation of NF- $\kappa B$ that induces TRAF6 in the RANKL-RANK signaling pathway. This suggests an inhibitory role of IFN- $\gamma$ in osteoclast formation, which should be paid close attention to, in clinics.

\section{Disclosure Statement}

The authors declare that there are no conflicts of interest regarding the publication of this paper.

\section{Acknowledgements}

This study was supported by national natural science foundation of China (No.81371980 and No.81772365). 


\section{Cellular Physiology Cell Physiol Biochem 2018;49:1512-1522 \begin{tabular}{l|l} 
and Biochemistry & $\begin{array}{l}\text { DOI: 10.1159/000493455 } \\
\text { Published } 2018 \text { The Author(s). Published by S. Karger AG, Basel } \\
\text { www.karger.com/cpb }\end{array}$
\end{tabular}

\section{References}

1 Biver E, Calmy A, Rizzoli R: Bone health in HIV and hepatitis B or C infections. Ther Adv Musculoskelet Dis 2017;9:22-34.

-2 Kapasa ER, Giannoudis PV, Jia X, Hatton PV, Yang XB: The Effect of RANKL/OPG Balance on Reducing Implant Complications. J Funct Biomater 2017;8:pii:E42.

-3 Liu Y, Duan D, Xin Y, Bai L, Li T, Li C, Xu Y: A review of the literature: antibiotic usage and its relevance to the infection in periodontal flaps. Acta Odontol Scand 2017;75:288-293.

4 Wang Z, Wang D, Yang D, Zhen W, Zhang J, Peng S: The effect of icariin on bone metabolism and its potential clinical application. Osteoporos Int 2017; DOI:10.1007/s00198-017-4255-1.

-5 Yang W, Han W, Qin A, Wang Z, Xu J, Qian Y: The emerging role of Hippo signaling pathway in regulating osteoclast formation. J Cell Physiol 2017; DOI:10.1002/jcp.26372.

6 Boyce BF, Xing L: Osteoclasts, no longer osteoblast slaves. Nat Med 2006;12:1356-1358.

-7 Asagiri M, Takayanagi H: The molecular understanding of osteoclast differentiation. Bone 2007;40:251264.

8 Kim JM, Jeong D, Kang HK, Jung SY, Kang SS, Min BM: Osteoclast precursors display dynamic metabolic shifts toward accelerated glucose metabolism at an early stage of RANKL-stimulated osteoclast differentiation. Cell Physiol Biochem 2007;20:935-946.

-9 Ciapetti G, Di Pompo G, Avnet S, Martini D, Diez-Escudero A, Montufar EB, Ginebra MP, Baldini N: Osteoclast differentiation from human blood precursors on biomimetic calcium-phosphate substrates. Acta Biomater 2017;50:102-113.

10 Ishida M, Amano S: Osteocalcin fragment in bone matrix enhances osteoclast maturation at a late stage of osteoclast differentiation. J Bone Miner Metab 2004;22:415-429.

11 Ren H, Ren H, Li X, Yu D, Mu S, Chen Z, Fu Q: Effects of intermedin on proliferation, apoptosis and the expression of OPG/RANKL/M-CSF in the MC3T3-E1 osteoblast cell line. Mol Med Rep 2015;12:6711-6717.

$>12$ Kong L, Wang B, Yang X, Guo H, Zhang K, Zhu Z, Liu J, Hao D: Picrasidine I from Picrasma Quassioides Suppresses Osteoclastogenesis via Inhibition of RANKL Induced Signaling Pathways and Attenuation of ROS Production. Cell Physiol Biochem 2017;43:1425-1435.

$\checkmark 13$ Wu Q, Zhou X, Huang D, Ji Y, Kang F: IL-6 Enhances Osteocyte-Mediated Osteoclastogenesis by Promoting JAK2 and RANKL Activity In vitro. Cell Physiol Biochem 2017;41:1360.

14 Hienz SA, Paliwal S, Ivanovski S: Mechanisms of Bone Resorption in Periodontitis. J Immunol Res 2015;2015:615486.

15 Liu Y, Zhang T, Zhang C, Jin SS, Yang RL, Wang XD, Jiang N, Gan YH, Kou XX, Zhou YH: Aspirin Blocks Orthodontic Relapse via Inhibition of CD4(+) T Lymphocytes. J Dent Res 2017;96:586-594.

16 Mori G, D’Amelio P, Faccio R, Brunetti G: Bone-immune cell crosstalk: bone diseases. J Immunol Res 2015;2015:108451.

17 Gaffen SL, Hajishengallis G: A new inflammatory cytokine on the block: re-thinking periodontal disease and the Th1/Th2 paradigm in the context of Th17 cells and IL-17. J Dent Res 2008;87:817-828.

18 Fox SW, Chambers TJ: Interferon-gamma directly inhibits TRANCE-induced osteoclastogenesis. Biochem Biophys Res Commun 2000;276:868-872.

19 Pang M, Martinez AF, Jacobs J, Balkan W, Troen BR: RANK ligand and interferon gamma differentially regulate cathepsin gene expression in pre-osteoclastic cells. Biochem Biophys Res Commun 2005;328:756763.

20 Takayanagi H, Ogasawara K, Hida S, Chiba T, Murata S, Sato K, Takaoka A, Yokochi T, Oda H, Tanaka K, Nakamura K, Taniguchi T: T-cell-mediated regulation of osteoclastogenesis by signalling cross-talk between RANKL and IFN-gamma. Nature 2000;408:600-605.

21 Li X, He L, Hu Y, Duan H, Li X, Tan S, Zou M, Gu C, Zeng X, Yu L, Xu J, Liu S: Sinomenine suppresses osteoclast formation and Mycobacterium tuberculosis H37Ra-induced bone loss by modulating RANKL signaling pathways. PLoS One 2013;8:e74274.

22 Li Q Zhang H, Yu L, Wu C, Luo X, Sun H, Ding J: Down-regulation of Notch signaling pathway reverses the Th1/Th2 imbalance in tuberculosis patients. Int Immunopharmacol 2018;54:24-32.

23 Kotake S, Nanke Y, Mogi M, Kawamoto M, Furuya T, Yago T, Kobashigawa T, Togari A, Kamatani N: IFNgamma-producing human $\mathrm{T}$ cells directly induce osteoclastogenesis from human monocytes via the expression of RANKL. Eur J Immunol 2005;35:3353-3363. 


\section{Cellular Physiology Cell Physiol Biochem 2018:49:1512-1522

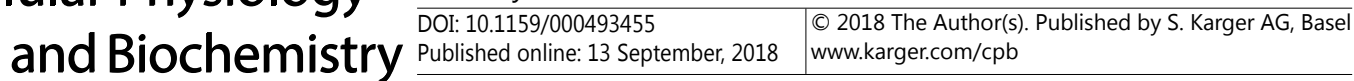 \\ Deng et al.: Anti-IFN- $\gamma$ Antibody Induced Osteoclast Formation}

24 Arron JR, Choi Y: Bone versus immune system. Nature 2000;408:535-536.

25 Arnez MFM, Ribeiro LSN, Barretto GD, Monteiro PM, Ervolino E, Stuani MBS: RANK/RANKL/OPG Expression in Rapid Maxillary Expansion. Braz Dent J 2017;28:296-300.

26 Wang J, Fu B, Lu F, Hu X, Tang J, Huang L: Inhibitory activity of linarin on osteoclastogenesis through receptor activator of nuclear factor kappaB ligand-induced NF-kappaB pathway. Biochem Biophys Res Commun 2017; DOI:10.1016/j.bbrc.2017.12.091.

-27 Kumar NP, Anuradha R, Suresh R, Ganesh R, Shankar J, Kumaraswami V, Nutman TB, Babu S: Suppressed type 1 , type 2 , and type 17 cytokine responses in active tuberculosis in children. Clin Vaccine Immunol 2011;18:1856-1864.

-28 Peresi E, Oliveira LR, da Silva WL, da Costa EA, Araujo JP Jr, Ayres JA, Fortes MR, Graviss EA, Pereira AC, Calvi SA: Cytokine Polymorphisms, Their Influence and Levels in Brazilian Patients with Pulmonary Tuberculosis during Antituberculosis Treatment. Tuberc Res Treat 2013;2013:285094.

29 Greco E, Quintiliani G, Santucci MB, Serafino A, Ciccaglione AR, Marcantonio C, Papi M, Maulucci G, Delogu G, Martino A, Goletti D, Sarmati L, Andreoni M, Altieri A, Alma M, Caccamo N, Di Liberto D, De Spirito M, Savage ND, Nisini R, et al.: Janus-faced liposomes enhance antimicrobial innate immune response in Mycobacterium tuberculosis infection. Proc Natl Acad Sci U S A 2012;109:E1360-1368.

30 Chen H, Cheng C, Li M, Gao S, Li S, Sun H: Expression of TNF-alpha, IFN-gamma, TGF-beta, and IL-4 in the spinal tuberculous focus and its impact on the disease. Cell Biochem Biophys 2014;70:1759-1764.

-31 Desvignes L, Ernst JD: Interferon-gamma-responsive nonhematopoietic cells regulate the immune response to Mycobacterium tuberculosis. Immunity 2009;31:974-985.

-32 Kohara H, Kitaura H, Fujimura Y, Yoshimatsu M, Morita Y, Eguchi T, Masuyama R, Yoshida N: IFN-gamma directly inhibits TNF-alpha-induced osteoclastogenesis in vitro and in vivo and induces apoptosis mediated by Fas/Fas ligand interactions. Immunol Lett 2011;137:53-61.

-33 Cheng J, Liu J, Shi Z, Jules J, Xu D, Luo S, Wei S, Feng X: Molecular mechanisms of the biphasic effects of interferon-gamma on osteoclastogenesis. J Interferon Cytokine Res 2012;32:34-45. 